\title{
Korelasi Stres dan Aktivitas Fisik dengan Tekanan Darah pada Penderita Hipertensi Essensial
}

\author{
Miko Eka Putri \\ Program Studi S1 Keperawatan STIKBA \\ Email : putri29iwan@gmail.com
}

\begin{abstract}
Hypertension is a global health problem. The prevalence of hypertension in Indonesia is $26.5 \%$ and there have been 9.4 million people out of 1 billion people in the world die from cardiovascular disorders. Data from the Jambi Provincial Health Office shows that hypertension ranks 2nd out of the 5 biggest diseases in Jambi. factors that affect blood pressure such as; age, stress, ethnicity, gender, daily variation, medication, activity, weight, and smoking. The purpose of this study was to determine the correlation between stress and physical activity with blood pressure. The method of this research is in essential hypertensive patients in the Working Area of Talang Bakung Health Center, Jambi City. This research is a quantitative study with a cross sectional approach. The study was conducted on 1 - 11 August 2018 with a sample of 41 people, purposive sampling technique. Data collection is done using guided interviews using a questionnaire. The results of the study were analyzed using the chi square test. The results showed that the majority of respondents 35 (85.4\%) experienced hypertension, some respondents 24 (58.5\%) experienced stress and most 26 (63.4\%) respondents had heavy physical activity. The results of statistical tests were obtained ( $p$-value $0.003 \& 0.018) p$-value $<0.05$, meaning that there was a significant relationship between stress and physical activity with blood pressure in essential hypertensive patients. The conclusion of the study is that, as severe as stress is deep in patients with hypertension, the higher the blood pressure and the more severe physical activity carried out will cause an increase in blood pressure. It is expected that nurses can provide health education to people with hypertension in order to avoid stress and reduce physical activity so there is no increase in blood pressure
\end{abstract}

Keywords:

Stress, Physical Activity, Blood Pressure

\section{PENDAHULUAN}

Hipertensi merupakan peningkatan tekanan darah sistolik lebih dari $140 \mathrm{mmHg}$ dan tekanan diastolik lebih dari $90 \mathrm{mmHg}$ (Brunner \& Suddarth, 2013). Menurut WHO (2014), Hipertensi adalah tekanan darah sistole $\geq 140$ $\mathrm{mmHg}$ dan tekanan darah diastole $\geq 90 \mathrm{mmHg}$.

Berdasarkan data dari World Health Organization (WHO) tahun 2013 diketahui bahwa hipertensi sering menimbulkan penyakit kardiovaskuler, ginjal dan stroke. Telah terdapat 9,4 juta orang dari 1 milyar orang didunia meninggal akibat gangguan kardiovaskuler. Prevalensi hipertensi masih tergolong tinggi, di negara maju prevalensi hiperensi sebesar 35\% dari populasi dewasa dan di negara berkembang prevalensi hipertensi sebesar $40 \%$ dari populasi dewasa.

Data Penderita Hipertensi di Indonesia yang didapat melalui pengukuran pada umur $>$ 18 tahun sebesar 25,8\%, tertinggi dibangka Belitung (30,9\%), Kalimantan (30,8\%), Kalimantan Timur $(29,6 \%)$ dan Jawa Barat $(29,4 \%)$. Hipertensi terlihat meningkat dengan bertambahnya umur dan hipertensi pada perempuan lebih cenderung lebih tinggi dari pada laki-laki (Riskesdas, 2013).

Hipertensi Essensial sampai saat ini penyebabnya belum diketahui dengan jelas. Namun, bisa dilihat dari faktor yang mempengaruhi tekanan darah seperti; usia, stress, etnik, jenis kelamin, variasi harian, obatobatan, aktivitas, berat badan, dan merokok
(Kozier,et al, 2010). Faktor yang mempengaruhi tekanan darah salah satunya adalah aktivitas fisik.

Menurut Riskesdas (2013) menunjukkan bahwa 48,2\% penduduk Indonesia kurang melakukan aktivitas fisik. Aktivitas fisik merupakan suatu kegiatan yang membutuhkan gerakan dan mengeluarkan energi. Aktivitas fisik memiliki banyak manfaat bagi kesehatan tubuh kita antaranya yaitu : untuk mengontrol tekanan darah, meningkatkan kapasitas jantung dan paru-paru, membantu menurunkan risiko penyakit serebrovaskular, memperbaiki mood, meningkatkan kapasitas kerja otot, meningkatkan imunitas, dan Membantu memperlambat penurunan densitas tulang.

Stres merupakan respon tubuh yang bersifat tidak spesifik terhadap tuntunan atau beban atasnya, apabila seseorang mengalami beban atau tugas yang berat tetapi orang tersebut tidak dapat mengatasi tugas yang dibebankan itu, maka tubuh akan berespon dengan tidak mampu terhadap tugas tersebut. Sumber stress ada 2 faktor yaitu: Internal, faktor internal stress bersumber dari diri sendiri. Eksternal, faktor eksternal stress dapat bersumber dari keluarga, masyarakat, dan lingkungan.

Berdasarkan data yang didapat dari Dinas Kesehatan Kota Jambi, bahwa penderita Hipertensi Essensial di 20 Puskesmas Kota Jambi, menunjukkan bahwa angka kunjungan pasien hipertensi mengalami peningkatan yaitu 
2505 pada tahun 2016 menjadi 3255 pada tahun 2017. Artinya 1 tahun terakhir terjadi peningkatan sebanyak 750 kasus.

Berdasarkan survey awal yang dilakukan pada 10 penderita Hipertensi di Wilayah Kerja Puskesmas Talang Bakung Kota Jambi pada tanggal 23-24 Mei 2018 didapatkan 6 orang dari 10 penderita Hipertensi pada saat dilakukan pemeriksaan tekanan darah didapatkan tekanan darah tinggi $>140 \mathrm{mmhg}$ untuk sistole dan $>90$ (untuk diastole). Mereka mengatakan bahwa tekanan darah meningkat karena stres dan karena banyak melakukan aktifitas. Berdasarkan latar belakang masalah diatas, maka penulis tertarik untuk melakukan penelitian tentang korelasi stres dan aktivitas fisik dengan tekanan darah pada penderita hipertensi essensial di Wilayah Kerja Puskesmas Talang Bakung Kota Jambi Tahun 2018.

\section{METODE PENELITIAN}

Penelitian ini merupakan penelitian kuantitatif dengan desain deskriptif analitik dan pendekatan cross sectional yang bertujuan untuk mengetahui hubungan antara stres dan aktivitas fisik dengan tekanan darah pada penderita hipertensi essensial di wilayah kerja Puskesmas Talang Bakung Kota Jambi. Populasi dalam penelitian ini adalah seluruh penderita hipertensi essensial di wilayah kerja Puskesmas Talang Bakung Kota Jambi sebanyak 188 orang penderita. Pengambilan sampel dalam penelitian ini menggunakan teknik purposive sampling yang berjumlah 41 orang penderita hipertensi essensial. Penelitian ini dilakukan pada 1-11 Agustus 2018. Pengumpulan data untuk stres dilakukan dengan menggunakan analisis univariat dan bivariat. Untuk mengetahui adanya hubungan kedua variabel yang diteliti peneliti menggunakan ujisquare.

\section{HASIL DAN PEMBAHASAN}

Hasil penelitian ini akan diuraikan dalam bentuk diagram dan tabulasi. Analisis yang digunakan adalah analisis univariat dan bivariat. Gambaran karakteristik responden yang ditampilkan berupa pendidikan dan lama menderita hipertensi. Untuk analisisbivariat menggunakan analisis chi square.

\section{Gambaran Responden}

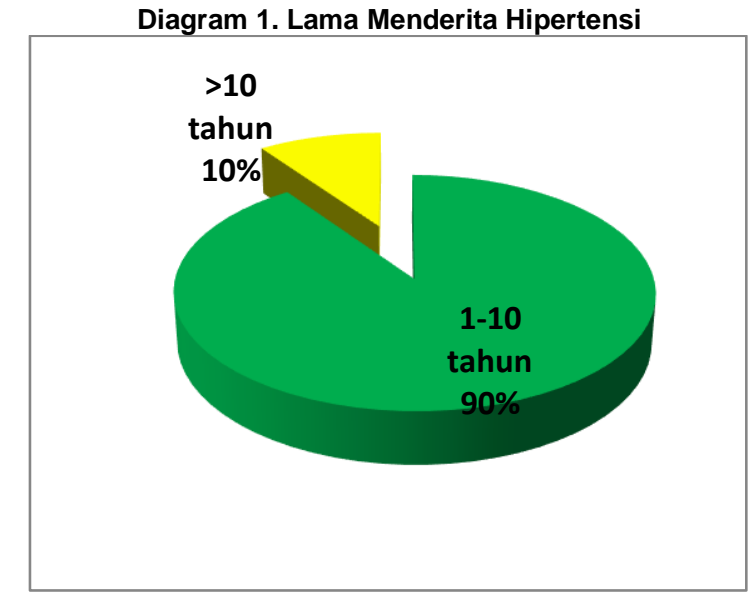

Diagram diatas menunjukkan bahwa hampir seluruhnya $(90 \%)$ responsen telah menderita hipertensi antara 1-10 tahun.

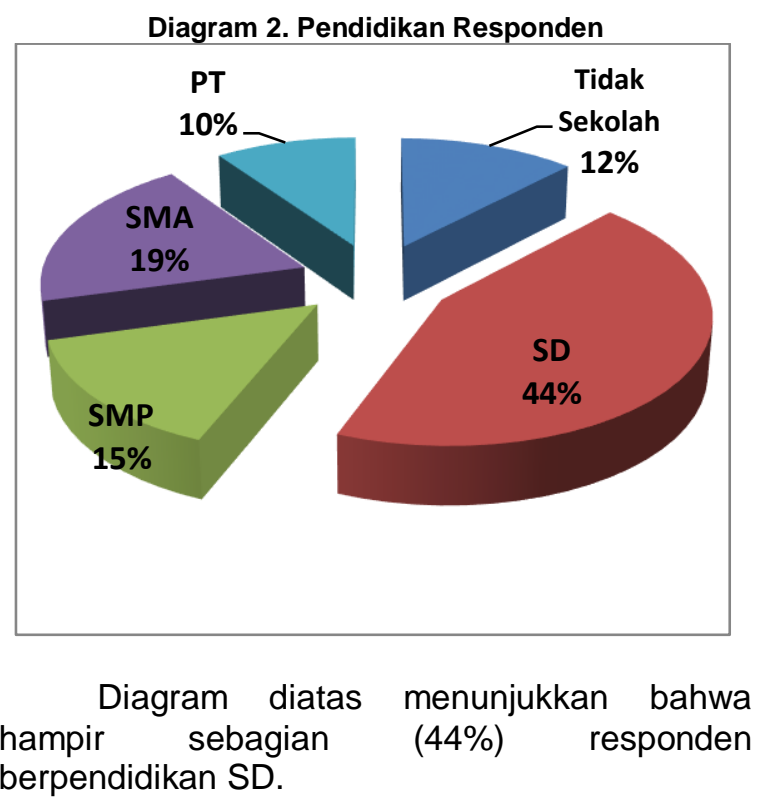

Analisis Univariat

Diagram 4. Distribusi Tekanan Darah

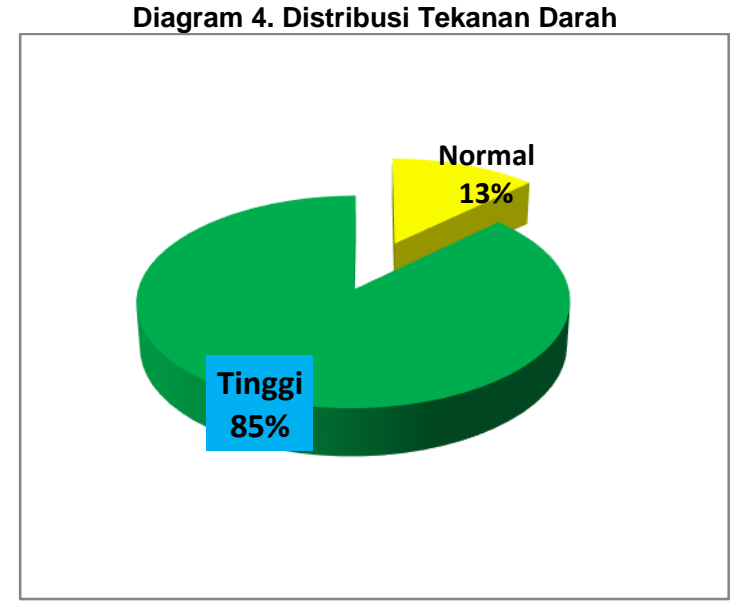


Berdasarkan diagram 1 diketahui bahwa sebagian besar $(85 \%)$ responden menunjukkan hasil tekanan darah tinggi.

Diagram 5. Distribusi Kondisi Stres

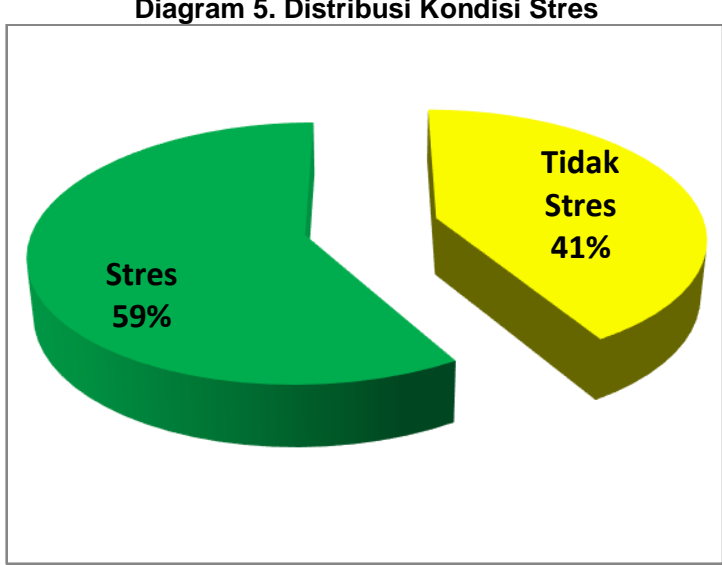

Berdasarkan diagram di atas diketahui bahwa sebagian (59 \%) responden dikategorikan stres.

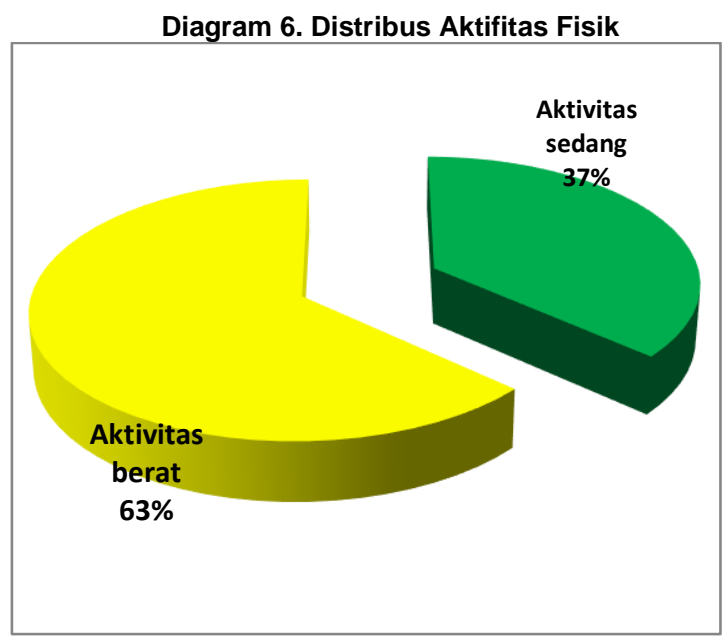

Diagram di atas menunjukkan bahwa sebagian besar responden melakukan aktifitas berat sehari- hari.

Analisis Bivariat

Analisis bivariat mengunakan uji chi- square.

Tabel 1 Hubungan Stres Dengan Tekanan Darah

\begin{tabular}{|c|c|c|c|c|c|c|c|c|}
\hline \multirow{2}{*}{ No } & \multirow{2}{*}{ Stress } & \multicolumn{5}{|c|}{ Tekanan Darah } & \multirow{2}{*}{ Jumlah } & \multirow{2}{*}{$\begin{array}{c}\text { P. } \\
\text { Value }\end{array}$} \\
\hline & & & ormal & & Tinggi & & & \\
\hline 1. & $\begin{array}{l}\text { Tidak } \\
\text { stres }\end{array}$ & 6 & $35,3 \%$ & 11 & $64,7 \%$ & 17 & $100 \%$ & \\
\hline 2. & Stres & 0 & $0,0 \%$ & 24 & $100 \%$ & 24 & $100 \%$ & 0,003 \\
\hline & Total & 6 & $14,6 \%$ & 35 & 85,4 & 41 & $100 \%$ & \\
\hline
\end{tabular}

Berdasarkan tabel diatas dapat dilihat dari 24 responden yang mengalami stres 100\% mengalami hipertensi. Uji statistik dengan Fisher's Exact didapatkan hasil $p$ value 0,003. Artinya terdapat hubungan yang bermakna antara stres dengan tekanan darah.
Berdasarkan hasil penelitian didapatkan bahwa beberapa responden yang mengalami tekanan darah tinggi disebabkan oleh faktor stres. Stres adalah satu kondisi ketika individu berespon terhadap perubahan dalam status keseimbangan normal.Stimulasi sistem saraf simpatis meningkatkan curah jantung dan vasokontriksi arteriol, yang kemudian akan meningkatkan tekanan darah, meskipun demikian nyeri yang hebat dapat menurunkan tekanan darah secara bermakna dengan menghambat pusat vasomotor dan memicu vasodilatasi (Kozier dkk, 2010).

Sumber stres yang dialami seseorang bisa dari internal maupun eksternal. Internal bersumber dari diri sendiri. Stresor individual dapat timbul dari tuntutan pekerjaan atau beban yang terlalu berat, kondisi keuangan, ketidakpuasan dengan fisik tubuh, penyakit yang dialami, masa pubertas, karakteristik atau sifat yang dimiliki, dan sebagainya. Eksternal stres dapat bersumber dari keluarga, masyarakat, dan lingkungan.Stresor yang berasal dari keluarga disebabkan oleh adanya perselisihan dalam keluarga, perpisahan orang tua, adanya anggota keluargayang mengalami kecanduan narkoba, dan sebagainya. Sumber stresor masyarakat dan lingkungan dapat berasal dari lingkungan pekerjaan, linkungan sosial, atau lingkungan fisik (Hidayat, 2009)

Stres dapat menyebabkan perasaan negatif atau yang berlawanan dengan apa yang diinginkan atau mengancam kesejahteraan emosional. Stres dapat mengganggu cara seseorang dalam menyerap realitas, menyelesaikan masalah, berfikir secara umum, dan hubungan seseorang dan rasa memiliki

Hasil juga menunjukkan bahwa dari 17 responden yang tidak mengalami stres tetapi tetap mengalami hipertensi. Hal ini disebabkan oleh pada penderita hipertensi mengalami penebalan dan penurunan elastisitas pebuluh darah, akibatnya dengan kondisi stres atau pun tidak stres penderita hipertensi akan menyebabkan peningkatan tekanan darah. Ada beberapa faktor yang dapat mempengaruhi tekanan darah seperti : genetik atau keturunan dimana salah satu orang tua dari responden mengalami penyakit yang sama. Usia, tekanan darah pada orang dewasa akan meningkat sesuai usia. (Kozier dkk, 2010).

Kondisi stres yang berlebihan akan mempengaruhi daya tahan atau kemampuan tubuh, akan tetapi, penyesuaian tubuh ini dapat menyebabkan gangguan baik fisik maupun psikis. Pengaruh hormon adrenalin dan hidrokortison yang di hasilkan sebagai reaksi tubuh terhadap stres bila berlebihan dan berlangsung dalam jangka waktu lama dapat menyebabkan rangkaian reaksi dari organ tubuh yang lain. Perubahan fungsional tekanan darah 
pada beberapa tempat dapat disebabkan oleh stres akut, bila berulang secara intermiten beberapa kali, dapat menyebabkan suatu adaptasi struktural hipertropi kardiovaskuler. Stres merupakan aktivitas saraf simpatis, peningkatan ini mempengaruhi meningkatnya tekanan darah secara bertahap. Apabila stres menjadi berkepanjangan dapat berakibat tekanan darah menjadi tetap atau semakin tinggi. Berdasarkan hasil penelitian ini $90 \%$ responden telah mengalami hipertensi selama < 10 tahun.

Tingkat Stres seseorang juga dipengaruhi oleh mekanisme koping seseorang. Mekanisme koping adalah setiap upaya yang diarahkan pada pelaksanaan stres, termasuk upaya penyelesaian masalah langsung dan mekanisme pertahanan yang digunakan untuk melindungi diri (Susilo, 2009).

Berdasarkan hasil penelitian dapat disimpulkan bahwa stres yang dialami penderita hipertensi akan dapat memicu terjadinya peningkatan tekanan darah, baik stressor yang bersumber dari diri sendiri maupun stressor yang bersumber dari luar diri. Untuk itu perawat harus mengidentifikasi sumber stres sebelum memberikan intervensi keperawatan, sehingga penderita hipertensi dapat menghindari stressor yang dapat menyebabkan meningkatnya tekanan darah penderita itu sendiri.

Tabel 2. Hubungan Aktifitas Fisik Dengan Tekanan Darah

\begin{tabular}{lllllllll}
\hline No & $\begin{array}{c}\text { Aktivitas } \\
\text { fisik }\end{array}$ & \multicolumn{2}{c}{$\begin{array}{c}\text { Tekanan darah } \\
\text { Normal\% }\end{array}$} & $\begin{array}{c}\text { Tinggi } \\
\%\end{array}$ & & & Jumlah & $\begin{array}{c}P \text { - } \\
\text { Value }\end{array}$ \\
\hline 1. Aktivitas & 5 & 33,3 & 10 & 66,7 & 15 & 36,6 & \\
$\begin{array}{l}\text { sedang } \\
\text { 2. Aktivias } \\
\quad \text { berat }\end{array}$ & 1 & 3,8 & 25 & 96,2 & 26 & 63,4 & 0,018 \\
Total & 6 & 14,6 & 35 & 85,4 & 41 & 100 & \\
\hline
\end{tabular}

Tabel diatas menunjukkan bahwa dari 26 reponden yang melakukan aktivitas fisik berat hapir seluruhnya $(96,2 \%)$ mengalami tekanan darah tinggi. Hasil uji statistik Fisher's Exact Test diperoleh $p$ - value 0,018 ( $p$-value $<0,05)$ yang dapat disimpulkan bahwa terdapat hubungan signifikan antara aktifitas fisik dengan tekanan darah pada penderita hipertensi essensial.

Aktivitas fisik yang terlalu berat akan memicu peningkatan tekanan darah. karena aktivitas fisik melibatkan kerja otot yang akan menghasilkan peningkatan kebutuhan energi (Soegih, 2009). Akibatnya jantung bekerja lebih ekstra untuk menyampaikan darah, oksigen dan nutrisi ke seluruh tubuh. Kerja jantung yang ekstra tersebut mengakibatkan tekanan darah penderita hipertensi menjadi meningkat. Untuk itu penderita hipertensi dianjurkan tidak melakukan aktivitas berat, tetapi tetap dianjurkan untuk melakukan olahraga.

Berdasarkan hasil peneliti sebagian responden jarang melakukan aktivitas fisik berat secara rutin seperti berolahraga dan jalan santai. Aktivitas yang biasa dilakukan responden seharihari adalah pekerjaan rumah tangga seperti memasak, mencuci, dan menyapu, mengangkat barang berat, mengangkat barang ringan, mengendarai kendaraan, berkebun, menonton tv, duduk ditempat kerja, dan olahraga berjalan yang dilakukan diwaktu tertentu saja.

Latihan fisik akan emberikan pengaruh yang baik terhadap berbagai macam sisitem yang bekerja di dalam tubuh, salah satunya adalah sistem kardiovaskuler, dimana dengan latihan fisik yang benar dan teratur akan terjadi efisiensi kerja jantung. Efisiensi kerja jantung ataupun kemampuan jantung akan meningkat sesuai dengan perubahan- perubahan yang terjadi.

Tekanan darah sistolik naik $8-12 \mathrm{mmHg}$ untuk setiap ekuivalen matabolik (MET lebih tinggi) diatas saat istirahat, suatu aktivitas yang setara dengan 2 MET membutuhkan dua kali jumlah oksigen, 3 MET membutuhkan tiga kali jumlah oksigen, dan seterusnya. Aliran darah lebih banyak dibutuhkan selama berolahraga, tubuh secara otomatis menurunkan tingkat ketahanan terhadap aliran darah didalam pembuluh darah selama berolahraga untuk memenuhi kebutuhan. Dengan demikian, tekanan diastolik akan turun dengan berolahraga. Orang yang berolahraga akan mengalami fenomena yang disebut pada hipotensi pasca olahraga atau penurunan tekanan darah. Hal ini dapat terjadi dengan interval olahraga kurang dari 10 menit pada intensitas olahraga ringan (kira-kira $40 \%$ dari denyut jantung maksimum).

Penurunan tekanan darah $5-7 \mathrm{mmHg}$ terjadi hingga 24 jam setelah berolahraga merupakan mekanisme dasar untuk mengurangi tekanan darah dengan program olahraga rutin. Dosis optimum olahraga adalah 30 menit aktivitas aerobik yang mengakibatkan meningkatnya denyut jantung dari $50-70 \%$ dari maksimum sesering mungkin dalam satu minggu, meskipun bagi sebagian besar orang, aktivitas aerobik yang paling banyak adalah berjalan (Divine, 2012).

\section{SIMPULAN}

a. Gambaran stres pada penderita hipertensi essensial adalah 24 responden (58,5\%).

b. Gambaran aktivitas fisik pada penderita hipertensi essensial adalah 26 responden $(63,4 \%)$.

c. Gambaran tekanan darah pada penderita hipertensi essensial hampir seluruhnya 35 responden $(85,4 \%)$.

d. Ada hubungan antara stres dengan tekanan darah pada penderita hipertensi essensial dengan $p$-value $0,003<0,05$. 
e. Ada hubungan antara akivitas fisik dengan tekanan darah pada penderita hipertensi essensial dengan $p$-value $0,018<0,05$.

\section{DAFTAR PUSTAKA}

Brunner \& Suddart. 2013. Keperawatan Medikal Bedah. Edisi 12. Jakarta : Penerbit Buku Kedokteran EGC.

Depkes RI. 2013. Riset Kesehatan Dasar 2013. Jakarta: Badan Penelitian dan Pengembangan Kesehatan Kementrian Kesehatan RI.

Dinas Kesehatan Kota Jambi. $2018 . \quad$ Data Penderita Hipertensi Di Seluruh Puskesmas yang Berada di Kota Jambi Tahun Anggaran 2016-2017. Jambi.

Divine gan G. 2012.Program Olahraga Tekanan Darah Tinggi. Jakarta : Citra Aji Parama.

Hidayat A Aziz Alimul. 2009. Kebutuhan Dasar Manusia. Jilid 1.Jakarta : Salemba Medika.

Hidayat A Aziz Alimul. 2009. Konsep Dasar Keperawatan. Edisi 2.Jakarta : Salemba Medika.

Kozier, et al. 2010. Buku Ajar Fundamental Keperawatan. Edisi 7.Vol 1. Jakarta :Penerbit Buku Kedokteran EGC.

Kozier, et al. 2010. Buku Ajar Fundamental Keperawatan.Edisi 7. Vol II. Jakarta :Penerbit Buku Kedokteran EGC.

Potter \& Perry. 2010. Fundamental Keperawatan. Edisi 7. Vol II.jakarta : Salemba Medika.

Riskesdas. 2013. Badan Penelitian Dan Pengembangan Kesehatan Kemeneterian Kesehatan RI.

Sari, dkk. 2018. Hubungan Kualias Tidur dan Aktivitas Fisik Dengan Tekanan Darah Pada Lansia Di Posyandu Lansia Desa Setrorejo. Surakarta.

Soegi \& Wiramihardja. 2009. Obesitas Permasalahan Dan Terapi Praktis. Jakarta : Sagung Seto.

Yuliani, dkk. 2016. Gambaran Faktor Resiko Aktvitas Fisik, Kualitas tidur Dan Stress Dengan Tekanan Darah Pada Lansia Tingkat Akhir Fakultas Teknik Universitas Diponegoro. Semarang. 